
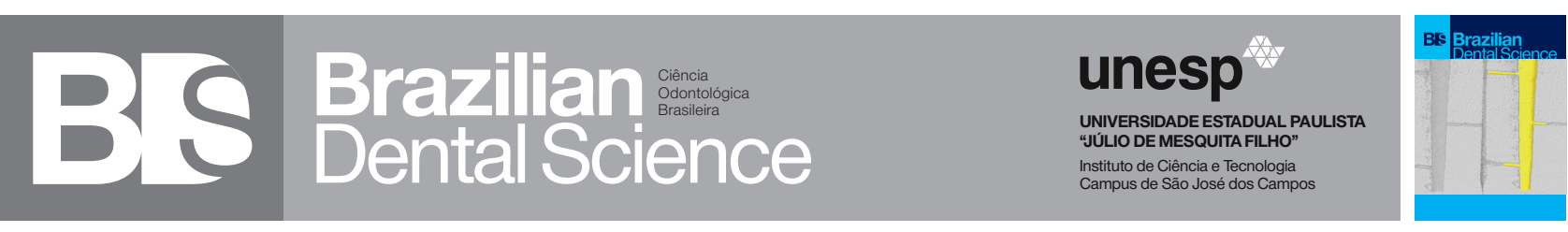

\title{
The influence of disinfection on dimensional stability of temporary crowns
}

\author{
A influência da desinfecção na estabilidade dimensional de coroas temporárias
}

Paula Carolina Komori de CARVALHO ${ }^{1}$, Lais Medeiros Ribeiro de ALMEIDA ${ }^{1}$, Sâmia Carolina Mota Cavalcanti SACOURAGUE ${ }^{1}$, Estevão Tomomitsu KIMPARA ${ }^{1}$, Tarcisio José de Arruda PAES JUNIOR ${ }^{1}$.

1 - São Paulo State University (Unesp) - Institute of Science and Technology - São José dos Campos - Department of Dental Materials and Prosthodontics - São José dos Campos - SP - Brazil.

\section{ABSTRACT}

Objective: Evaluate the influence of different disinfection methods on the dimensional stability of temporary acrylic resin crowns. Material and Methods: A metallic die with two different marks at the margin was used to prepare the specimens with two different resins (bis-acrylic resin-Structur, acrylic resin-Dencrilay). They were divided into eight groups $(n=8)$, determined according to the disinfection methods (microwave, acetic acid, 1\% hypochlorite) and control. The marginal adaptation was recorded using an optical microscope (50X) comparing two different marks on the margin of the crowns with 2 points along the entire circumferential margin before and after disinfection methods. Results: Results were compared statistically by ANOVA and Tukey's test $(\mathrm{p} \leq 0.05)$. The two-way ANOVA showed statistical difference between types of materials. No significant differences were found between disinfection methods and interaction of factors. Conclusion: All procedures affected the marginal adaptation however temporary crowns made by bis-acrylic resin demonstrate higher dimensional stability.

\section{KEYWORDS}

Dimensional stability; Disinfection; Temporary crowns.

\section{RESUMO}

Objetivo: Avaliar a influência de diferentes métodos de desinfecção na estabilidade dimensional de coroas temporárias de resina acrílica. Material e Métodos: um molde metálico com duas marcas diferentes na margem foi utilizado para preparar os espécimes com duas resinas diferentes (resina bis-acrílica - estrutura, resina acrílica-Dencrilay). Eles foram divididos em oito grupos $(n=8)$, determinados de acordo com os métodos de desinfecção (microondas, ácido acético, $1 \%$ de hipoclorito) e controle. A adaptação marginal foi registrada usando um microscópio óptico (50X) comparando duas marcas diferentes na margem das coroas com 2 pontos ao longo de toda a margem circunferencial antes e após os métodos de desinfecção. Resultados: os resultados foram comparados estatisticamente por ANOVA e teste de Tukey $(p \leq 0,05)$. A ANOVA de dois fatores mostrou diferença estatística entre os materiais utilizados. Não foram encontradas diferenças significativas entre os métodos de desinfecção e a interação dos fatores. Conclusão: Todos os procedimentos afetaram a adaptação marginal, porém as coroas temporárias feitas em resina bis-acrílica demonstram maior estabilidade dimensional.

\section{PALAVRAS-CHAVE}

Estabilidade dimensional; Desinfecção; Coroas temporárias 


\section{INTRODUCTION}

$\mathrm{N}$ owadays a large number of patients that needs dental treatment are motivated by the functional and aesthetic requirements in this context curative treatments often are indicated for fixed prostheses, by extensive destruction or loss of one or more dental elements [1-3].

Oral rehabilitation with fixed partial denture does not allow in most cases complete treatment in a single session because it is usually involve lab procedures, thus the need for an interim temporary prosthesis $[2,3]$. This prosthesis can be performed through different techniques, to provided excellent biological and mechanical requirements [1,3-5].

The temporary prosthesis is extremely important for building the permanent prosthesis because it will give professional guidance for better contour, color choice, placements maxillo-mandibular, dental and periodontal recovery, among others [1,3-5].

Considering that temporary crowns are the prototypes of final restorations, when a temporary crown is cemented on the tooth for a certain period of tempo we have to take into account the marginal adaptation of these [3-5]. Another major concern of healthcare should be biosecurity, seeking the professional protection and that of their patients, which is justified by the overall increase in the incidence of infectious diseases [6]. In dental practice adjustments and repairs on temporary prostheses contaminated by fungi, bacteria or virus should follow a disinfection process for subsequent cemented [7]. The success of the process is obtained by the correct choice of disinfection agent [7]. Glutaraldehyde, sodium hypochlorite, acetic acid, chlorhexidine, and the irradiation by microwave, are considered high-level disinfectant $[4,5,8,9]$.

The most commonly used material for making the temporary crowns is chemically activated acrylic resin, supplied in powder form (polymer) and liquid (monomer) due to ease of processing, aesthetic and cost. The acrylic resin is considered semi-critical article, since it comes in contact with mucosa and thus must be subjected to sterilization or disinfection [7], however, sterilization is not applicable, because its heat distortion temperature is relatively low $\left(75^{\circ} \mathrm{C}\right)[9]$.

For resins the best mechanism of disinfection is chemical disinfection, which removes the most microorganisms [5]. The immersion of acrylic resins in disinfectant solutions may result in marginal leakage on prosthesis, since low dimensional stability is inherent characteristic of the resins it increases proportionally on time in mouth [10]. Moreover, some studies show that different disinfecting agents affect the physical properties of heat polymerized acrylic resins, such as hardness, strength and roughness [7].

An alternative material to fabricated temporary crowns is bis-acrylic resin, being a high-strength and durability material $[4,6,10,11]$. The use of microwave energy as a method of disinfection has favorable characteristics such as low cost, lack of toxicity, easy to use besides quick and efficient action against microorganisms $[7,10]$.

The evaluation of these materials and method of disinfection is important considering its properties on the reduction of microorganisms during dental treatment. Based on these questions, this study aimed to evaluate the influence of different disinfection methods on marginal stability of temporary crowns of acrylic resin and bis-acrylic.

\section{MATERIALS \& METHODS}

An metallic master model simulating a posterior tooth dental preparation for crowns was molded in two steps using a condensation silicon (Zetaplus, Zermack Clinical, BadiaPolesine, Rovigo, Italy) in mass and light consistency (Oranwash L, Zermack Clinical, BadiaPolesine, Rovigo, Italy). 64 molds were obtained in plaster stone type IV (Durone, Dentsply, Petrópolis, RJ, Brazil).

The plaster models (Figure 1A) were waxed up (wax castings, Kota, São Paulo, SP, Brazil) and a crown was sculpted in the shape of a molar (Figure 1B). This assembly was performed as described above, and the obtained mold filled with acrylic resin selfcuring (Dencrilay, Dencril, Caieiras, SP, Brazil) 
(Figure 1C) or bis-acrylic resin (Structur, Voco, $\mathrm{GmbH}$, Cuxhaven, Germany) (Figure 1D).

The acrylic resin was manipulated and during the dough stage was introduced into the mold where subsequently repositioned to the plaster model, keeping the position originally having found for both reference points identified in both the mold as the template. Waited at least 30 minutes to separate the mold and verification of the crown obtained in resin.

After finishing the crowns was visualized and measured marginal fit with the standard metal for the initial value of adaptation. The crowns were stored in distilled water for a period of 48 hours at $37^{\circ} \mathrm{C}$ individually and distributed as disinfection methods.

For the distilled water (control group), disinfection with acetic acid or disinfection with $1 \%$ sodium hypochlorite, the specimens were immersed individually in glass container for ten minutes, washed in running water and repositioned in the plaster models. For the microwave disinfection, we adopted an disinfection protocol established by Neppelenbroek et al. (2003) the specimens were immersed individually in $200 \mathrm{~mL}$ of distilled water, and performed a 3 minutes 650W, 30 minutes after the crowns were repositioned in the corresponding plaster models.

To measure the dimensional alteration was comparatively analyzed before and after disinfection processes the distance between the points previously identified in two regions: one in standard and one on metallic mold where it was determined the relationship between these points with the reading taken with an optical microscope $(50 x)$ in micrometers.

The values of the difference between the measurements before and after performing the procedures of disinfection were converted to percentages for better viewing of the data. Values close to $100 \%$ accounted for less discrepancy.

\section{RESULTS}

The values obtained were subjected to analysis of variance considering a significance level of 5\% and Tukey test. The two way analysis of variance showed no statistically significant difference between the disinfection methods $(\mathrm{p}=0.535301)$. In the analysis of variance between the overall averages of temporary crown there was no statistically significant difference $(\mathrm{p}=0.584247)$.

Table 1 - Means (\%) and standard deviations for acrylic resin (Dencrilay, Dencril) and bis-acrylic resin (Structur, Voco).

\begin{tabular}{|c|c|c|}
\hline $\begin{array}{c}\text { Disinfecting } \\
\text { methods }\end{array}$ & Acrylic resin & Bis-acrylic resin \\
\hline Distilled water & $98.04(25.51)$ & $99.87(19.53)$ \\
\hline Microwave cycle & $83.64(30.83)$ & $91.58(34.11)$ \\
\hline AceticAcid & $76.76(29.13)$ & $120.66(46.81)$ \\
\hline 1\% Sodiumhypochlorite & $84.69(30.94)$ & $114.17(69.08)$ \\
\hline
\end{tabular}

Analysis of variance showed statistically significant difference between resin groups $(\mathrm{p}=0.032431)$. The bis-acrylic resin showed higher means values that were closer to $100 \%$. Suggesting that the marginal discrepancy of the resin evaluated cervical specimens was lower compared to the acrylic resin considering all disinfectants treatments (Table 2).

Table 2 - Means of discrepancy of all groups and Tukey test.

\begin{tabular}{|c|c|c|}
\hline Resingroups & Mean (\%) & $\begin{array}{c}\text { Homogeneous- } \\
\text { groups }\end{array}$ \\
\hline Acrylic & 85.78 & $\mathrm{~A}$ \\
\hline Bis-Acrylic & 106.57 & $\mathrm{~B}$ \\
\hline
\end{tabular}

\section{DISCUSSION}

One aspect to be considered in this study is that the marginal discrepancy was a factor analysis of the dimensional changes of the resins, so when the observed percentage values should take into account how these values have distanced themselves from the reference and not, if this value was greater or less than one hundred percent. The intention is to avoid a false interpretation that values below one hundred percent represent an increase in adapting the assembly prosthesis/model.

The importance of disinfection procedures is relevant today and need to establish secure protocols. Studies that evaluated the effects 
of disinfection agents may promote on dental materials used are still relevant.

The low dimensional stability is inherent characteristic of resins and increases proportionally to the time in mouth [4,5], thus, analyzing the results of this study reinforces the idea that disinfection methods can increase the marginal discrepancy of temporary crowns, fact which results in damage to the remaining tooth structure and or surrounding tissue.

Disinfectant solutions water-based and methyl polymethacrylate (PMMA) contained in the resin have a characteristic absorption of water by diffusion, which exhibit significant effects on mechanical and dimensional properties $[6,10]$. The water absorption results in linear expansion of the resin and interferes on polymer chain which usually begins to show plasticization because it relaxes the tensions of material $[5,10,12]$.

When comparing thermal cycling (hot/cold) on acrylic resins, the increase in temperature generates higher marginal discrepancy in temporary crowns [1]. The literature mentions some studies where the placing of acrylic resins in a microwave oven for disinfection has provided efficient results in terms of eliminating microorganisms with ten minutes of irradiation without causing any significant dimensional changes in the acrylic resin $[13,14]$ but observes that the protocol established by Neppelenbroek et al.[7] and adopted in this study contradicts this statement because all groups showed discrepancy.

In the case of microwave energy, possible effects on the material properties can be explained by the fact that microwave energy promote heating of the material structure, and that can be translated into something advantageous, for example, increased conversion of monomer in polymer and consequent increase in mechanical strength. In contrast, this heating can promote deleterious effect on the material, dimensional changes and consequent loss of marginal adaptation of the prosthesis $[15,16]$.

The dimensional change of the acrylic resin can also be attributed to the presence of residual monomer and the free radical on polymerized material. When this material is heated, could provide an additional polymerization reaction and result in contraction $[4,5]$.

For acrylic resins literature cites changes in their properties when their contact with substances such as acetic acid (vinegar), supported by the results of this study which show marginal discrepancy on the disinfection process. The group disinfected by vinegar showed greater loss of marginal adaptation regardless of resin used, although there was no statistically significant difference compared to the other groups.

For the bis-acrylic resin, the literature describes as composite consisting of a combination of UDMA based resin and microparticles that increased the mechanical resistance to abrasion and decreased contraction of polymerization,satisfactory physical properties, including marginal finish and the potential to impart and maintain polish. $[11,15,16]$. The bis-acrylic resin integrity was statistically superior to acrylic resin; bis-acrylic resin had lower discrepancy near the cervical margin, or greater dimensional stability compared to acrylic resin.

Considering the proposal as routine disinfection of prostheses, the marginal adaptation should be improved. Relining procedures of the pieces should be emphasized to provide an excellent adaptation $[2,3]$.

\section{CONCLUSION}

Within the limitations of this in vitro study, the following conclusions were made: the disinfection methods of temporary crowns in acrylic and bis-acrylic resin resulting in dimensional changes. These changes were independent of the type of disinfection. It was also observed that the comparison between the two resins showed that the bis-acrylic resin had the best marginal adaptation compared to the acrylic resin, being more indicated to use on temporary crowns for the variable proposed in this study. 


\section{REFERENCES}

1. Ehrenberg D, GI Weiner, S Weiner. Long-term effects of storage and thermal cycling on the marginal adaptation of provisional resin crowns: a pilot study.J Prosthet Dent. 2006;95(3):230-6.

2. Barghi N,EW Simmons.J.The marginal integrity of the temporary acrylic resin crown.JProsthetDent. 1976;36(3):274-7.

3. Regis RR, Soriani NC, Azevedo AM, Silva-Lovato CH, Paranhos HF, de Souza RF.Effects of ethanol on the surface and bulk properties of a microwaveprocessed PMMA denture base resin.J Prosthodont. 2009 Aug;18(6):489-95. doi: 10.1111/.1532-849X.2009.00475.x.

4. Balkenhol M, Ferger P,Mautner MC, Wöstmann B. Provisional crown and fixed partial denture materials: mechanical properties and degree of conversion. Dent Mater.2007 Dec;23(12):1574-83.

5. Balkenhol M,Knapp M, Ferger P,Heun U,Wöstmann B.Correlation between polymerization shrinkage and marginal fit of temporary crowns.Dent Mater. 2008 Nov;24(11):1575-84. doi: 10.1016/j.dental.2008.07.001.

6. Rodrigues Garcia RC1, Joane Augusto de S Jr, Rached RN, Del Bel Cury AA. Effect of denture cleansers on the surface roughness and hardness of a microwave-cured acrylic resin and dental alloys.J Prosthodont. 2004 Sep;13(3):173-8.

7. Neppelenbroek KH, Pavarina AC, Spolidorio DM, Vergani CE, MimaEG, Machado ALEffectiveness of microwave sterilization on three hard chairside reline resins.Int J Prosthodont. 2003 Nov-Dec;16(6):616-20.

8. Padbury A Jr1, Eber R, Wang HL, Interactions between the gingiva and the margin of restorations.J Clin Periodontol. 2003 May;30(5):379-85.
9. Asad T, WatkinsonAC, HuggettR.The effects of various disinfectant solutions on the surface hardness of an acrylic resin denture base material.Int $J$ Prosthodont. 1993 Jan-Feb;6(1):9-12.

10. Robinson FB, HovijitraS. Marginal fit of direct temporary crowns. J Prosthet Dent 1982;47(4):390-2.

11. Young HM, SmithCT,MortonD. Comparative in vitro evaluation of two provisional restorative materials. J ProsthetDent. 2001;85(2):129-32.

12. MaT, JohnsonGH, GordonGEEffects of chemical disinfectants on surface characteristics and color of three fixed prosthodontic crown materials. J ProsthetDent, 1999. 82(5):600-7.

13. Rohrer MD, BulardRA. Microwave sterilization. J Am Dent Assoc.1985;110(2):194-8.

14. Consani RLX, Lira AF, Mesquita MF, Consani S. Linear dimensional change in acrylic resin disinfected by microwave energy. Ciên Odontol Bras. 2006;9(2):34-9.

15. SartoriEA, SchmidtCB, Walber LF, Shinkai RS. Effect of microwave disinfection on denture base adaptation and resin surface roughness.Braz Dent J. 2006;17(3):195-200.

16. Nunes de Mello JA1, Braun KO, Rached RN, Del Bel Cury AA. Reducing the negative effects of chemical polishing in acrylic resins by use of an additional cycle of polymerization.J Prosthet Dent. 2003 Jun;89(6):598-602.

\section{Paula Carolina Komori de Carvalho}

\section{(Corresponding address)}

São Paulo State University (Unesp) - Institute of Science and Technology - São

José dos Campos - Department of Dental Materials and Prosthodontics - SP

- Brazil. Av. Francisco José Longo, 777 - Bairro São Dimas, CEP: 12245-000

São José dos Campos, São Paulo, Brazil. Fax number: (+551239479307); Telephone number: $(+551239479307)$

Date submitted: 2018 Mar 23 Accept submission: 2018 Jun 13 